\title{
Pragmatic Competence Study in Task-Based English Class
}

\author{
Chen Xiaohui \\ Chengdu College of University of Electronic Science and Technology of China, L.A.S Department \\ Chengdu, Sichuan, 611731
}

\begin{abstract}
The study focuses on the development of English majors' language performance with the implement of the taskbased English project on CDUESTC campus. The finding is that the group of English juniors' pragmatic competence has developed gradually during the period of accomplishing the English radio program's organization and broadcast. Through the finding, the study shows that the English juniors' pragmatic competence could be pushed up by the task-based language teaching method, the "natural approach".
\end{abstract}

Keywords-Task-based English teaching; Pragmatic competence; Natural approach

\section{INTRODUCTION}

With the further integration of the global economy, English communication and application skills have been the necessary equipment for college students, especially for the English majors. In the language teaching, there long live the contradictions as between the linguistic forms and the linguistic meaning, the development of the language system and the training of language communication. The task-based English teaching method arose in the 1980s is a studentcentered approach, which is developed from cognitive theories and advocate that the students' attention would be allocated reasonably in the process of completing the elaborately designed tasks in the communication environment; only along this way both the language system and communicative competence of the students could keep sustained and balanced development. Skehan (1995) mentioned that the acquisition process of second language is different from that of the native language [1]. Second language learning is more cognitive than the native one, and students tend to pay attention to the meaning of language in communication activities. The students' attention is limited in the information processing environment, in another words, while paying enough attention to the linguistic instances or facts, the students would definitely ignore the internal syntactic pressure, which would hamper the development of the linguistic system; therefore the language teaching should offer realistic environment in which students could have chances to discover the linguistic forms and speed up the development of interlanguage system. This is the theoretical basis of taskbased teaching. The concept of communicative competence derives from the pragmatic competence according to Hymes (1964), he believes that a person's pragmatic ability does not only refer to the ability to make the proper sentences, but also the ability to use language properly [2]; hence, he puts forward the concept of communicative competence. Skehan (1996) elaborated three different designing patterns of task-based teaching: structure-based, communication-driven and intermediate position [3]. "Structure-based" teaching tasks emphasize the use of linguistic forms in task completing, such as the use of a particular language structure in completing a certain task. "Intermediate position tasks" does not only value the naturalness and authenticity of the tasks, but also put great emphasis on designing and choosing tasks, with which the students would have some more practical chances to call their attention to linguistic forms so that the students could speed up the interlanguage development. The "communicative" teaching tasks emphasize the nature and authenticity of the tasks. Its advocates, Willis (1996) pointed out that the more authentic the task is the more progresses the students would achieve in it, i.e. task should not be designed only from the angle to develop a particular language structure; the implementation of task should not just benefit the conformity of language, or it would turn the task into a kind of language structure performance [4]. The need of the realistic environment should be the driving force for task design, so as to promote the language acquisition in an interactive way and promote the interlanguage development. This study considers that college English juniors should be equipped with enough linguistic knowledge that the "communication-driven" tasks in realistic environment would facilitate English majors' pragmatic competence and communication skills greatly. Therefore, this study aims to investigate the role of "communication-driven" teaching task in the pragmatic competence of English majors.

\section{RESEARCH DESIGN}

The teaching task in this research is to make the English juniors of CDUESTC to participate in the English radio program's organization and broadcast; and the English juniors have been responsible for the forty-five minutes morning broadcasting which will last a whole year on the campus. The morning show is guided by the teacher and participated by the group of English juniors who are responsible for selection, recording, cutting, organizing and broadcasting of the show; The students have participate in the task of the real language environment and would do some reflections on the task. The main research methods are reflection and classroom recording; The research object contains six third-year English majors in the department of Liberal Arts, Chengdu college, University 
of Electronic Science and Technology of China. The contents in reflection mainly reflect students' attitudes and their personal opinions on participating in this English task. During the first week of the English task, the teacher invited six English juniors to the stage and gave a trial lecture (20 minutes) according to the text of the English dialogue (text A) in the book of the first grade in junior high school. During the 12 weeks to 16 weeks of the semester, the teacher, please the six English juniors again one by one according to do the trial lectures ( 20 minutes) based on the other text (text B) in the same book of the first grade in junior high school; and the two trial lectures' lecturing has been recorded. The results of the two trial lectures' recording is mainly used to analyze the pragmatic competence in the task-based language class. The contents of the two trial lectures in this study are chosen from the same book of the first grade in junior high school, the contents of the two trial lectures are consequently balanced in difficulty; this study analyzes the English juniors' communicative pragmatic competence in English lecturing in the two trial teaching classes by analyzing mainly these juniors' classroom language.

\section{RESEARCH RESULTS AND DISCUSSIONS}

In the analysis of classroom language used by these English juniors in the two trial lectures, the study adopted 17 classification methods of the teachers' classroom language characteristics classified by Amy (1985) [5]. But some of language characteristics in the 17 classification methods have not been identified in the recording collections of the two trial lectures, that is to say, some of them have not been used by the English juniors; hence they would not be mentioned in this study; but the research has added the use of humor and personal comment by the English juniors in their classroom communication of the two trial lectures. This study has transformed the recordings of the English juniors' trial lectures into text, classified the different classroom communicative terms and marked the number of times that they appeared in two recordings according to Amy's (1985) classification, as the following table:

TABLE I. CLASSROOM LANGUAGE USED BY THE ENGLISH JUNIORS IN THE TWO TRIAL LECTURES

\begin{tabular}{|l|c|c|c|c|c|c|c|c|c|c|c|}
\hline \\
$\begin{array}{l}\text { Categories of } \\
\text { classroom language }\end{array}$ \\
Check trial lectures
\end{tabular}

As the above table shows, from the longitudinal comparison of the classroom language of the two trial lectures, through about three months' implementation of the task-based English teaching, the classroom language used by the junior students of English major in the second trial lecture A increases significantly than that in the first lecture $\mathrm{B}$; it is apparent that the task-based English teaching method facilitates the English major students' pragmatic competence apparently; From the reflection of the English juniors, all the six students in the program support the implementation of the task-based teaching method. Some of them said: "I prefer and cherish this task-based way of learning, it contains practice; I am afraid of the reverse way of teaching, the teacher-oriented courses". In the reflections, some student added: "I seldom allow many listeners to focus on my words, especially in English. After this experience, I have improved my mental quality, and I have noticed many shortcomings of my English expression, such as unnecessary catchphrases". There are many reflections that expressed the similar thoughts, and furthermore, the study found that almost all the students in the task have focused on the forms of language used in classroom communication once or twice, recognized the logic tags used to ignore, understood the value of listeners' aspects and did their best to organize and modify their wanted pragmatic markers.

The study found that, the students could not interact with the listeners effectively in the trial lectures A, they often made the lecturing like talking about themselves without necessary interaction and confirmation of the listeners' status, which is presented into the following four kinds of specific usage of the pragmatic markers. Firstly, ,the study found, in the trial lecture $\mathrm{A}$, that students were not only less 
likely to use the "check" markers that enable the listeners to know the progress of the lesson and check the listeners' status, but also they didn't get used to taking the lecturing rhythm from the angle of the listeners into consideration; In addition, the six English majors tended to repeat the marker "ok" monotonously as the prompt in the two trial lecture A and $\mathrm{B}$ to indicate that they were about to move into the next part, or to express the confirming the response. Furthermore, the study found that almost all of the six English juniors did their lecture A without the pragmatic markers indicating a reward or some better advice, such as "very nice" or "it would be better if you ..."; However, after more than three months of the implement of the task, the six English majors learned to consider the status of the listeners, and began to enrich their language use in the classroom communication. The sixth student of the English juniors, reinforced the use of the "check" markers in his trial lectures B, such as "do you agree" to know about the listeners' situation or their reactions to some certain pedagogic events, and the pragmatic markers such as "you see" to check the common knowledge between himself and the listeners.

"The communication is the kind of process that the two parties involved in it have to constantly supplement and extend the cognitive context"( He Zhaoxiong, 2000) [6]. The purpose of communication is to realize mutual knowledge and lead to the best results. According to this analysis, the pragmatic marker, "You know" in social communication, often conveys to the listener that the following contents is a common knowledge or general consensus among them. In real life, teachers often use the pragmatic marker, "you know" to remind students that the following statement is a kind of mutual knowledge -- that is, "the knowledge in textbooks". In the trial lecture A, the study found that the six English students carried less "you know" in their lecturing, and let alone the other pragmatic markers of the same range like "see", "you see" or "listen". With the implement of broadcast task and the guidance of teachers, the study found that some of the six English juniors started to use in the trial lecture $B$ the pragmatic markers as "you know" and even used it effectively.

Another finding in the study is that the six English juniors did not incline to use the "repetition" markers or "paraphrase" markers in the self-correcting or reaffirming context in both trial lectures A and B. To some extent, the finding could be interpreted into the limit of the English juniors' pragmatic competence in the classroom communication; furthermore, some students start to be aware of the application of some pragmatic markers, but in terms of percentage, few of them could apply these markers actively, in another words, the students have not converted declarative knowledge into procedural knowledge, let alone the active application of them. It can also be reflected in the study that in the classroom environment, the English junior have not given enough emphasis on the strategy of interpersonal communication, and lack enough communicative ability that could push them forward from the current language status.

Furthermore only the harmonious atmosphere could yield a better teaching result in the classroom. If the opinions of the two parts in communication are inconsistent with each other, application of the pragmatic markers such as "mitigator of face-threatening act" or "fuzzy language" could meet the requirement to avoid the threat to the counter part (Su Xiaomei, 2014) [7]. With the analysis of the trial lecture A and B, the study found that the six English junior can hardly use the mitigators, for instance, all of them use less "well", "sort of", or "kind of", etc. in their lecturing. Of these mitigators, when "well" is used by the speaker as an attitude marker to remind the listeners to be mentally prepared, as it is likely to imply a kind of reservations about the other person's views, and a different opinion would be uttered soon (Fung, L\&R. Carter. 2007) [8]. The application of such pragmatic markers has prevented speech from being too blunt and hurtful effectively. However, this study found that "well" only appeared three in the analysis of the trial lectures. The same as "ort of" and "kind of". On the contrary, the study found that many of the six English juniors followed the politeness principles in the two trial lectures to express command while choosing imperative language or euphemism, they chose to use euphemism, which may be affected by the English fundamental education the students received.

Finally, the study found that although almost all the students were nervous during the two trial lectures, there were still some students carrying out their lectures with humor. After two months of broadcasting training, the six English juniors accomplished their trial lecture B with selfconfidence; it's apparent that their psychological quality has been improved with the implement of the task, so that they could be brave to show their oral English in public. For instance, in the trial lecture $\mathrm{B}$, the first student to do the lecture took a good advantage of an unexpected "OH" uttered by a listener to respond humorously with "a very, very good /ou/, by the way, that was perfect pronunciation of /ou/".

\section{CONCLUSION}

The study found that the task-based English teaching does facilitate the students' English pragmatic competence after about a semester's training; in addition, with the teacher's guide, on the one hand, the six English major students learned how to use English to spread good English resources to other students in the accomplishment of the task-based English project, and their classroom communicative pragmatic competence has be enhanced as well; on the other hand, the accomplishment of completing the task stimulates and promotes the students' enthusiasm for English learning and English communication.

Secondly, one of the incidental findings of this study is that the trial lectures of senior English majors will facilitate their transition from the role of the student to the role of the teacher, that is to say, they could experience the transformation from the "knowledge-receiver" to the "knowledge-discoverer or task-planner" ; Language could be transformed from the " knowledge itself" to the necessary "tool" in completing tasks; the language students would be the "active executors" other than the "passive receivers" in these tasks. These practical chances are 
valuable and rare for English majors. These English juniors reflected in the reflection like that "English can be used in such an unexpected way that I could complete a task with it, the feeling is amazing."

In the end, as the project does not finish completely, this study will be continued at least more than six months to observe whether the English juniors' pragmatic competence could be developed steadily and how it could be developed effectively.

\section{REFERENCES}

[1] Krashen S. The Input Hypothesis: Issues and Implications [M]. New York: Longman, 1985.

[2] Hymes, D. (ed). Language in Culture and Society. New York: Harper and Row, 1964.

[3] Skehan, P. A framework for the implementation of task-based instruction. Applied Linguistics, 17/1: 38-63,1996.

[4] Willis, J.1996. A Framework for Task-based Learning [M]. London: Longman press.

[5] Amy, T.B. Analyzing Input and Interaction in Second Language Classroom. RELC Journal 16-1 (8-30), 1985.

[6] He Zhaoxiong, 2000, A New Introduction to Pragmatics.[M]. Shanghai: Shanghai Foreign Language Education Press.

[7] Su Xiaomei, "Bupani+V"as a discourse marker of a mitigator of face-threatening act $[\mathrm{J}]$. Language Teaching and Linguistic Studies, 2014(6).

[8] Fung, L\&R.Carter.2007.Pragmatic markers and Spoken English: Native and Learner Use in Pedagogic Settings[J]. Applied Linguistics28:410-439. 